\title{
FISHERY OF THE UÇÁ CRAB Ucides cordatus (LINNAEUS, 1763) IN A MANGROVE AREA IN CANANÉIA, STATE OF SÃO PAULO, BRAZIL: FISHERY PERFORMANCE, EXPLOITATION PATTERNS AND FACTORS AFFECTING THE CATCHES
}

\author{
Luis Felipe de Almeida Duarte ${ }^{1, *}$, Ricardo Santos Duran ${ }^{1}$, \\ Jocemar Tomasino Mendonça ${ }^{3}$ and Marcelo Antonio Amaro Pinheiro ${ }^{2}$ \\ ${ }^{1}$ Universidade Estadual Paulista "Julio de Mesquita Filho" \\ Instituto de Biociências - Campus de Rio Claro \\ (Avenida 24 A, 1515, 13506-900, Rio Claro, SP, Brasil) \\ ${ }^{2}$ Universidade Estadual Paulista "Julio de Mesquita Filho" \\ Campus Experimental do Litoral Paulista (CLP) \\ (Praça Infante Dom Henrique, s/n, Parque Bitaru, 11330-900, São Vicente, SP, Brazil) \\ ${ }^{3}$ Instituto de Pesca (APTA/SAA/SP) \\ (Av. Prof. Besnard s/nº, Morro São João, 11990-000 Cananéia, SP, Brasil) \\ *Corresponding author: duarte.mepi@gmail.com
}

http://dx.doi.org/10.1590/S1679-87592014068906203

\begin{abstract}
A B S T R A C T
The fishery of the mangrove crab (Ucides cordatus) is one of the oldest sources of food, income and extractive activity in the estuarine systems of Brazil. The state of São Paulo has the largest population of any Brazilian state, and the city of Cananéia, in the Brazilian southeast has the highest recorded level of exploitation of the uçá-crab. Since 1990, this species has been under intense exploitation pressure due to the unauthorized use of a type of trap called 'redinha'. This type of fishing gear is considered harmful and is prohibited by Brazilian law, although its use is very common throughout the country. This study aims to evaluate the exploitation patterns of $U$. cordatus based on landing data and monitoring of the crab fishermen to verify the population structure of the crab stock and to identify the factors that influence the catches. A general view of the sustainability of the fishery for this resource is also provided for five defined mangrove sectors (areas A to E) at Cananéia. For this purpose, fishery data were recorded during 2009-2010 by the Instituto de Pesca (APTA/SAA-SP), and monitoring of the capture procedures used by two fishermen was conducted to obtain biometry data (CW, carapace width) and gender data for the captured crabs. The redinha trap was very efficient $(86.4 \%)$ and produced sustainable catches because the trapped crabs were legalsized males $(\mathrm{CW}>60 \mathrm{~mm})$, although some traps are lost or remain in the mangrove swamps and can cause pollution by introducing plastic debris. The fishery data were evaluated with a General Linear Model (GLM) based on six factors: the characteristics of the crab fishermen, the time of capture (by month and year), the lunar phase, the productive sector and the reproductive period. The individual crab fishermen's empirical knowledge, the year of capture and the productive sector were the strongest influences on the crab catch per unit effort (CPUE). Differing extraction patterns were found in the five sectors examined in the Cananéia estuary. These findings underscore the need for a reassessment of the prohibition of the trap's use, raising discussion as to its possible construction with biodegradable materials, thus ensuring profitable and sustainable catches through a local participatory management process.
\end{abstract}

\section{RESUMO}

A pesca do caranguejo-uçá (Ucides cordatus) é uma das mais antigas atividades extrativas para a obtenção de fonte de alimento e renda nos sistemas estuarinos do Brasil. O Estado de São Paulo é o mais populoso e a cidade de Cananéia, localizada no sudeste, tem o maior volume registrado de captura do caranguejo-uçá para a região. Desde 1990, esta espécie vem sofrendo intensa pressão pesqueira pelo uso indiscriminado de um tipo de armadilha conhecida como "redinha". Este tipo de arte de pesca é considerado uma ameaça à população do caranguejo, sendo proibido pela legislação brasileira, embora seu uso seja comum em todo o país. Este estudo teve como objetivo avaliar os padrões de exploração de $U$. cordatus com base em dados de desembarque, bem como do 
monitoramento das capturas pelos catadores, com o intuito de verificar a estrutura populacional do estoque e identificar os fatores que vêm influenciando os rendimentos pesqueiros da espécie. Uma visão geral da sustentabilidade pesqueira foi também elaborada para cinco setores de pesca estabelecidos (áreas de A a E) em Cananéia. Para este propósito, dados sobre as pescarias foram registrados durante 2009-2010 pelo Instituto de Pesca (APTA/SAA-SP), bem como o acompanhamento das capturas de dois pescadores foi realizado para se obter dados de biometria (CW, largura da carapaça) e gênero dos animais capturados. Embora algumas armadilhas tenham sido perdidas/deixadas nos manguezais, promovendo certa poluição pela introdução desses detritos plásticos, estas foram consideradas eficientes $(86,4 \%)$ na captura do caranguejo-uçá, bem como corretas como instrumento de captura, uma vez que $100 \%$ dos espécimes por elas capturados eram machos com tamanho acima daquele permitido por lei $(\mathrm{CW}>60 \mathrm{~mm})$. Os dados sobre as pescarias foram avaliados utilizando-se o modelo geral linearizado (MGL), com base em seis fatores explicativos: os diferentes pescadores, o período de captura (por mês e ano), a fase lunar, o setor produtivo e o período reprodutivo. O conhecimento empírico dos pescadores de caranguejo, o ano da captura e do setor produtivo foram os principais fatores explicadores da variabilidade na captura de caranguejo por unidade de esforço (CPUE). Diferentes padrões de exploração foram observados nos cinco setores analisados no estuário de Cananéia. Os resultados obtidos ressaltam a necessidade de uma reavaliação na proibição do uso da armadilha "redinha", abrindo discussão sobre sua confecção com materiais biodegradáveis, assegurando, assim, capturas rentáveis e sustentáveis por meio de uma gestão participativa local.

Descriptors: CPUE; General Linear Model; Exploitation pattern; Mangrove; Ucides cordatus. Descritores: CPUE; Modelo Geral Linearizado; Padrões de explotação; Manguezal; Ucides cordatus.

\section{INTRODUCTION}

Most Brazilian artisanal fishing is based on estuarine species or on those that spend the larger part of their life cycle in estuarine systems, especially in mangrove areas (SCHAEFFER-NOVELLI; CINTRÓN-MOLERO, 1999; PINHEIRO et al., 2008). The food items from these sources were very important to the first Amerindians of the Brazilian coast, as demonstrated by deposits of food debris (called shell mounds, or 'sambaquis', in Brazil) dated to 10,000 years ago. These deposits consist of shells, fragments of crustacean carapaces and fish skeletons (EGGERS et al., 2008). The long history of capture and consumption of these estuarine items has allowed the diversification of fishing gear as well as the development of new techniques and methods for improving the success of the fisheries (VANNUCCI, 1999).

One of the most important crab species found on the Brazilian coast is Ucides cordatus (called the 'uçá'-crab in Brazil). This species has great economic and social value and is used by artisanal communities as a source of food and income (FISCARELLI; PINHEIRO, 2002; DALABONA, et al., 2005; WUNDERLICH, et al., 2008; PINHEIRO; RODRIGUES, 2011). To harvest the species, a fisher inserts one arm directly into the crab's burrow (a technique termed 'braceamento') (PINHEIRO; FISCARELLI, 2001) and removes the crab barehanded or, in some cases, with the aid of a tool (e.g., a metal hook, a cutting iron instrument called 'vanga' or a wooden instrument called a 'chuncho') (PINHEIRO; FISCARELLI, 2001; LEGAT et al., 2005). BOTELHO et al. (2000) describe the 'redinha', an artisanal trap widely used by Brazilian crab fishermen and constructed with a thin plastic thread obtained from raffia bags (PINHEIRO; FISCARELLI, 2001). During recent years, the use of this type of trap for the extraction of mangrove crabs has spread to increasing numbers of local communities on the southern coast of São Paulo State (MENDONÇA; PEREIRA, 2009).

The redinha is attached to the branches removed from mangrove trees and installed near the opening of a burrow. The plastic threads are placed inside the burrow, and the crab is captured a few hours later. Despite the ease with which these traps can be manufactured and installed and their substantial capture efficiency, this technique is prohibited by Brazilian law (IBAMA, 2003b), primarily due to the resulting juvenile mortality (SPARRE; VENEMA, 1998), the occurrence of passive (or 'ghost') fishing by traps that are lost or remain at the fishing site and the increase in the pollution of mangrove areas caused by undegraded trap material (BOTELHO et al., 2000; ALVES et al., 2005; LEGAT et al., 2005, 2006; JANKOWSKY et al., 2006). These problems have been of concern since the nineties, when crab fishermen from neighboring states (e.g., Rio de Janeiro) migrated to the Cananéia region and introduced this alternative capture technique. These fishermen used the redinha traps to initiate an exploratory crab fishery, increasing the intensity of capture in response to the decrease in the market prices of this crustacean. These changes posed problems for the established crab fishermen in the same area. Currently, there are no reports of harvesting by the traditional braceamento method. The new opportunities for more efficient harvesting have promoted the growth of the crab fishery in many coastal regions of Brazil in recent years (BOTELHO 
et al., 2000; ALVES et al., 2005; PASSOS; DI BENEDITTO, 2005; JANKOWSKY et al., 2006; ANDRADE et al., 2007; MENDONÇA; PEREIRA, 2009; NASCIMENTO et al., 2011). In northeast Brazil, BOTELHO et al. (2000) estimated that $1 \mathrm{~m}$ of Rhizophora mangle roots/trap is cut to allow attachment of the trap's plastic threads to the vegetation. According to these authors, the major damage resulting from redinha traps is associated with the $17 \mathrm{~kg} /$ year of plastic thread used for trap construction. This material increases the pollution of the mangrove swamps due to the inappropriate discarding of traps cited above. Although these traps have been used in the fishery since the nineties (BOTELHO et al., 2000), there continues to be a lack of information about the number of traps/day used by one crab fisherman and about the number of traps lost in the mangrove areas; the lack of information about the number of effective traps is even more serious. Therefore, even though prohibited by law, this kind of trap has been in widespread use all over Brazil (particularly in the south-east), so our study may provide information about its impact and a better understanding for its use on the part of the managing agencies.

In Brazil, $U$. cordatus was previously categorized as an overexploited species or a species threatened with overexploitation (AMARAL et al., 2005). Moreover, the FAO (2013) has warned that the possible overexploitation of fish stocks can not only result from substantial resource exploitation but also, in certain cases, from minimal levels of fishing effort, as recently documented for the lobster Scyllarides deceptor (DUARTE et al., 2010). In Brazil, two laws address the management of the $U$. cordatus fishery, one for the south-southeastern resource and the other for the north-northeastern resource (IBAMA, $2003 a, b)$. Both laws establish a minimum size $(60$ $\mathrm{mm}$ carapace width, $\mathrm{CW}$ ), the protection of ovigerous females and the closure of the fishery during the reproductive season. However, basic knowledge of the patterns of exploitation of this resource and the factors affecting the catch of the species is limited; this information is important for maximizing the protection and recovery of the population to ensure the sustainability of the resource (SPARRE; VENEMA, 1998) and is relevant due to the current lack of management of this species at the national level cited by DIAS-NETO (2011). Additionally, studies evaluating the level of fishing pressure that will affect crab populations are particularly important (FAO, 2013).

São Paulo State has the greatest population and the largest impacted mangrove area of any Brazilian state due to its extensive centers of industrialization, port facilities and inadequately regulated urbanization in the areas bordering its estuaries (PINHEIRO et al., 2008). These developments have harmed many crab fishermen except in the mangrove forests located in the southern areas of the state, especially Cananéia and JuréiaItatins, where certain mangrove areas are still preserved. The Cananéia region provides the largest fishing income in the state and is the location of the state's largest community of crab fishermen. For this reason, the evaluation undertaken in this study and future monitoring programs are important for preserving the current fishing activity. The $U$. cordatus fishery is affected by the harvesting techniques used by the crab fishermen in the mangrove environment as well as by the intensity of the fishery, the local landscape and the influence of temporal harvesting patterns.

Within this broad context, the present study aims to evaluate the patterns of exploitation of $U$. cordatus using redinha trap fishery based on landing data and on the monitoring of crab fishermen during their activities in the fishery. These investigations will allow comparative analyses of the population structure of the crabs and will serve to identify the principal factors determining the yields of the fishery. The resulting information will serve to present a general view of the sustainability of the fishery in five mangrove areas in Cananéia, southern São Paulo State. The findings of the study represent a necessary first step toward the maintenance of healthy and sustainable stocks of $U$. cordatus.

\section{Material ANd Methods}

\section{Study Area and Fishing Sectors}

The municipality of Cananéia has several conservation areas that integrate a Mosaic of Conservation Units (MCU) called 'Jacupiranga' and characterized by the presence of traditional cultures represented by: quilombolas (descendants of African slaves), Guarani Indians and caiçaras (peasants). These communities interact within a territory consisting of both insular and continental areas, an urban center on Cananéia Island and natural areas preserved in state parks (e.g., the State Park of Cardoso Island), and an extensive estuarine area of approximately 9.13 ha $\left(=91,330 \mathrm{~km}^{2}\right)$ of mangrove habitat (HERZ, 1991). For the purposes of this study, the area (Fig. 1) was divided into five fishery production sectors (designated A through E) based on similarities in the characteristics of the mangrove forests and according to the geographical coordinates associated with the specific features described in Cunha-Lignon et al. (2009). The characteristics of these fishery production sectors are as follows: 
Sector A: This extensive sector includes several Protected Areas (PAs): the State Park of Cardoso Island (SPCI), the Sustainable Development Reserve of Itapanhoapina (RDSI) and the Extractive Reserve of Tumba Island (ERTI). This sector is inhabited by a fishing community and is located near the small neighborhoods of Ariri and Taquari. Mangroves are abundant in the southern portion of the sector, but generally are distributed in very narrow strips and more concentrated near the banks of the estuary. It is possible that this characteristic of the area is due to the specific hydrodynamic regime produced by the funneling of the sea in the vicinity of a small submerged sandbank. The sector is affected by the substantial freshwater inflow from rivers with headwaters located on the mainland and on Cardoso Island. For this reason, the area is considered the best preserved and most ecologically sustainable tract in the Cananéia region.

Sector B: This sector includes extensive mangrove areas comprising two Extractivist Reserves (ERs), called Mandira and Taquari. This sector is relatively close to Cananéia city and to several neighborhoods (Taquari, Retiro and Mandira). It is located at the convergence of two estuarine regions (called seas Cubatão and Cananéia). The sector is directly influenced by winds, by the waves produced by the tides at Cananéia Bar and by the inflow of rivers from the mainland, allowing the formation of shoals and islands due to sedimentation.
Sector C: This sector includes a relatively large urban area where crab fishermen reside (e.g., in Carijó, Acaraú and Cubatão Port). Intense sedimentation occurs at the river mouths. Additionally, several vacation homes, housing estates and tourist facilities are to be found here. Of all the sectors considered in the study, this one appears to experience the greatest anthropogenic pressure due to the discharge of untreated sewage and pollution resulting from trash disposal.

Sector D: This sector includes extensive and wellpreserved mangrove areas. It is also influenced by the Cubatão and Cananéia estuarine 'seas' and includes two fishing neighborhoods, São Paulo Bagre and Pedrinhas. Sport fishing is a primary tourist activity in this area with some reports by fishermen on the lower impact of the crab fishery in this sector than in the other study sectors.

Sector E: This sector is surrounded by the most highly disturbed mangrove areas of Cananéia city and Comprida Island. It includes the Agrossolar neighborhood (near São Paulo Bagre), where many second homes are located. Boat traffic is intense throughout the year. Visits by tourists are frequent, due especially to the high density of porpoises and seabirds. Sector E is similar to Sector B in that it is influenced directly by the hydrodynamic conditions produced by the Cananéia bar. A large sandbank (called Gamboa Bananal) lies near Sector E.

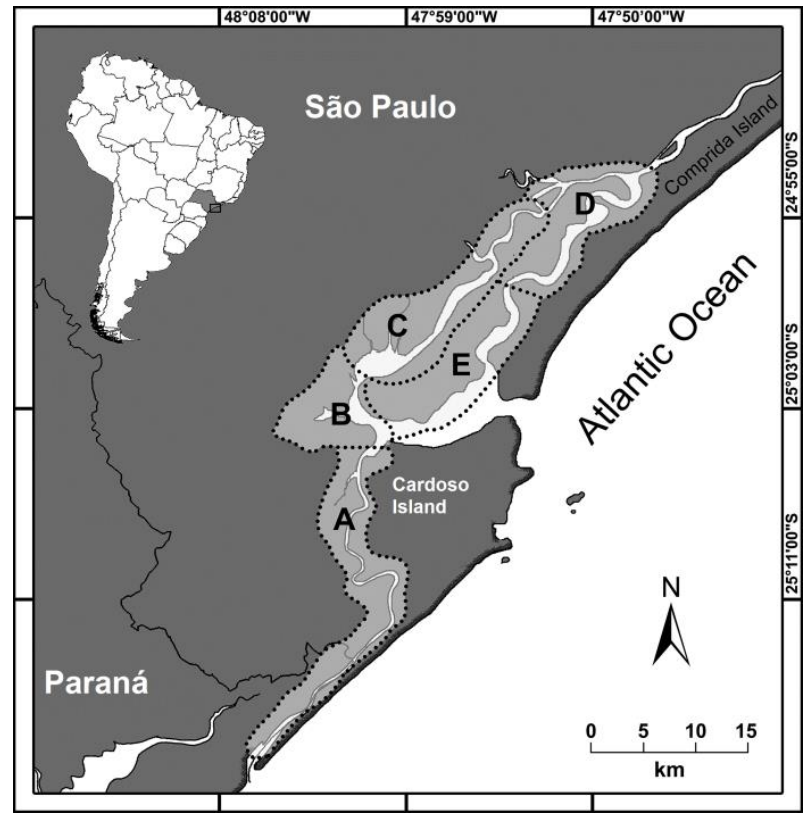

Fig. 1. Environmental Protection Area (EPA) of Cananéia-Iguape-Peruíbe (CIP) in southeastern São Paulo State, showing the five fishing sectors (A through E) defined for the Ucides cordatus fishery in the Cananéia estuary. 


\section{Commercial Capture Samples: Catch Monitoring}

Specific information on redinha trap fisheries is lacking in the literature, especially with reference to Brazil, where these traps are prohibited by law (DIAS-NETO, 2011). Two crab fishermen were, therefore, accompanied during their capture activities in Sector C (specifically located at $24^{\circ} 55^{\prime} 04.9^{\prime \prime} \mathrm{S}$ $47^{\circ} 54^{\prime} 04.0^{\prime} \mathrm{W}$ ) to obtain data on captures (production) and on lost traps and the failure of traps to capture crabs. In all, 450 traps were tested. A portion of the catch (221 specimens) was randomly sampled for biometric measurement.

The crabs were examined in the laboratory two days after capture. This two-day period is similar in length to the time during which crabs are stored by the fishermen prior to delivery to the buyers. Each animal was identified (MELO, 1996) and sexed by analyzing the abdominal morphology and the number of pleopods (PINHEIRO; FISCARELLI, 2001). Following the same procedures used by PINHEIRO and HATTORI (2006), all pereiopods were checked against the information that had previously been recorded to document any losses of pereiopods during capture and storage. The $\mathrm{CW}(\mathrm{mm})$ was measured with a vernier caliper $(0.05 \mathrm{~mm})$, and the wet weight (WT) (g) was measured with a precision balance $(0.01$ g). These data were used to obtain a statistical summary of each biometric variable and to build a histogram based on the population composition by $\mathrm{CW}$ size classes.

The participating crab fishermen whose fishing activities were monitored in this study were asked particular questions to gather additional information about their fishing activities. Systematized questionnaires were, therefore, applied to the fishermen. The questions asked were about: fishing site, captures, price at which the crabs were sold, quantity of crabs lost and failure of traps. Unfortunately, in view of the fact that the trap is prohibited by law, only two fishermen agreed to participate in this investigation. According to them, fishing for the uçá crab occurs mostly using this fishing gear and the fishery composition (sex and size of the specimens) does not vary greatly by season. Thus, the findings may be considered to be largely a reflection of local fishing conditions.

\section{Capture Effort and Production Analysis}

Additional data on the production of the commercial crab fishery were obtained between January 2009 and December 2010 by the Statistical Fishery Laboratory of the 'Instituto de Pesca' (APTA/SAA-SP). These results were obtained at specific strategic locations associated with commercial fishing and/or at the landing points in Cananéia city used by the fishery. Data were collected on catches (crab production), fishing effort (the number of traps), the identity of the crab fishermen and the fishing sector where the catches were made. The locations of the fishery were classified according to the five fishing sectors, A through E, defined in this study for the mangroves of Cananéia (Fig. 1).

The catch per unit effort (CPUE) is considered to represent a meaningful index of the relative abundance of the uçá crab; the number of traps is used as the measure of fishing effort (SPARRE; VENEMA, 1998). The calculations of CPUE (kg/trap) were based on the total catch $(\mathrm{kg})$ and the number of traps. The CPUE data were log transformed and tested for normality (Shapiro-Wilk (SW) test, (ZAR, 1999). A General Linear Model (GLM) (CRAWLEY, 2006) was used to determine the significance level for six factors (month, fisherman, fishing sector, phase of the moon, year, and biological period) that could potentially influence the variations in CPUE. The GLM used for this analysis represented CPUE with the following equation:

$$
\begin{aligned}
& C P U E=\mu+\alpha_{\text {fisherman }}+\beta_{\text {year }}+\gamma_{\text {fishing sector }}+\varphi_{\text {month }}+ \\
& \theta_{\text {biological period }}+\emptyset_{\text {moon }}+\varepsilon
\end{aligned}
$$

where $\mu$ denotes the intercept, $\varepsilon$ the error relative to a normal distribution and the other Greek letters the six exogenous factors associated with the capture of individuals: $\alpha$ fisherman (the individual crab fisherman), $\beta_{\text {year }}$ (2009 and 2010), $\gamma$ fishing sector (Sectors A to E), $\varphi$ month (twelve months), $\theta$ biological period (reproductive and non-reproductive periods) and $\varnothing_{\text {moon }}$ (full, new, waxing and waning moons). This model assumes a normal-gamma distribution for the CPUE data based on the best fit of this distribution to the dataset. The statistical analysis and graphics were produced with Microsoft $^{\circledR}$ Excel $^{\circledR}$ and $R$ 2.5.0 (IHAKA and GENTLEMAN, 1996).

\section{Results ANd Discussion}

Commercial Catch Samples: Catch Monitoring

General Characteristics

The monitoring of the crab fishermen showed that $86.4 \%$ of the traps were effective (i.e., captured at least one crab). These traps captured a total of 389 crabs, of which $91.5 \%$ were legal-sized males (i.e., $\mathrm{CW} \geq 60 \mathrm{~mm}$ ) in accordance with the Brazilian laws published for the south-southeastern regions of the country (IBAMA, 2003a, b). Only $8.5 \%$ of the crabs captured during monitoring were females $(n=13)$ or juveniles $(n=10)$. Because these small crabs were not of market size, they were immediately released by the fishermen. This practice is common among 
fishermen in the Cananéia region. The occurrence of this practice is interesting and important. It may confirm that the fishermen show an environmentally motivated concern for this resource. Alternatively, and most likely, the small size of the crabs may imply that they are not commercially acceptable in terms of the various requirements of the buyers. Diele et al. (2005) also observed that the crab catches in the Caeté estuary, state of Ceará (Brazil), were composed of males and that this practice may have contributed to the maintenance of the stock. A detailed evaluation of the field data shows that a small number of crabs $(\mathrm{n}=10 ; 2.5 \%)$ were captured by raccoons (Procyon cancrivorus Cuvier, 1798). This carnivorous mammal eats only the viscera of the crabs, leaving the carapace and pereiopods on the floor of the mangroves near the crab burrows. The fishermen gather the remains (primarily the chelipeds) for consumption by their families. A total of $10 \%$ of the traps $(n=45)$ failed to capture crabs. Presumably, these traps would remain on the sediment until the next collection. A small percentage of the traps $(3.6 \%)$ were lost and forgotten by the fishermen. These traps would remain in the mangrove areas and become a potential source of trash. Some of them would be recovered by other fishermen; the two fishermen questioned in the monitoring program considered the traps a common resource.

\section{Biometry and Commercial Condition}

The crabs captured during the study $(n=389)$ were packed in bags by the fishermen during the fishery. Subsequently, a random selection of over $50 \%$ of the captured crabs (subsample) was taken from all the bags to obtain a number of individuals that represented the capture made by the two fishermen. In all, 221 specimens $(38.6 \mathrm{~kg}$ ), corresponding to $56.8 \%$ of the total catch, were used for this purpose. All of the specimens were males; they ranged in size from 60 to $84 \mathrm{~mm} \mathrm{CW}$ (average $71.7 \pm 1.1 \mathrm{~mm}$ ) and had an average weight of $174.8 \pm 29 \mathrm{~g}$. These data confirm that the crabs captured were legal-sized and were used by the fishermen for commercial purposes (Fig. 2), namely, sale to the people of the community. This commercial activity occurs, for example, at Iguape (SP) (FISCARELLI; PINHEIRO, 2002). These latter authors state that the crabs are sold at various prices that depend on the interest of the buyers. In Cananéia (SP), the crab buyers pay an average of US $\$ 4.00$ per dozen for live crabs. This price is slightly higher than that observed by FISCARELLI and PINHEIRO (2002) in 2000 at Iguape (US\$ 3.00). A loss of locomotor appendages by the crabs can result from storage and results, inevitably, in a decrease in the commercial value of the product. Such losses can also make it impossible to sell the crab; as a result, the crab may be discarded or returned to the mangroves. In this study, $45.7 \% \quad(n=101)$ of the crabs were intact. This value falls within the range of 26 to $66 \%$ reported by Legat et al. (2006). Of the total captured, $36.2 \%$ $(n=80)$ were still considered for sale, even with a maximum loss of two pereiopods, and $18.1 \%(n=40)$ were retained by the fishermen for consumption by their families. However, individuals lacking chelipeds were excluded from sale because these appendages represent up to $41 \%$ of the total wet weight and $14 \%$ of the meat yield in this species (PINHEIRO et al., in prep.). Overall, $81.9 \%$ of the crabs were used for commercial purposes, generating a financial yield of US\$ 56.00 per two working days. A financial loss of US\$ 12.00 was represented by the $18.1 \%$ of the crabs that were not sold due to a loss of appendages during storage.

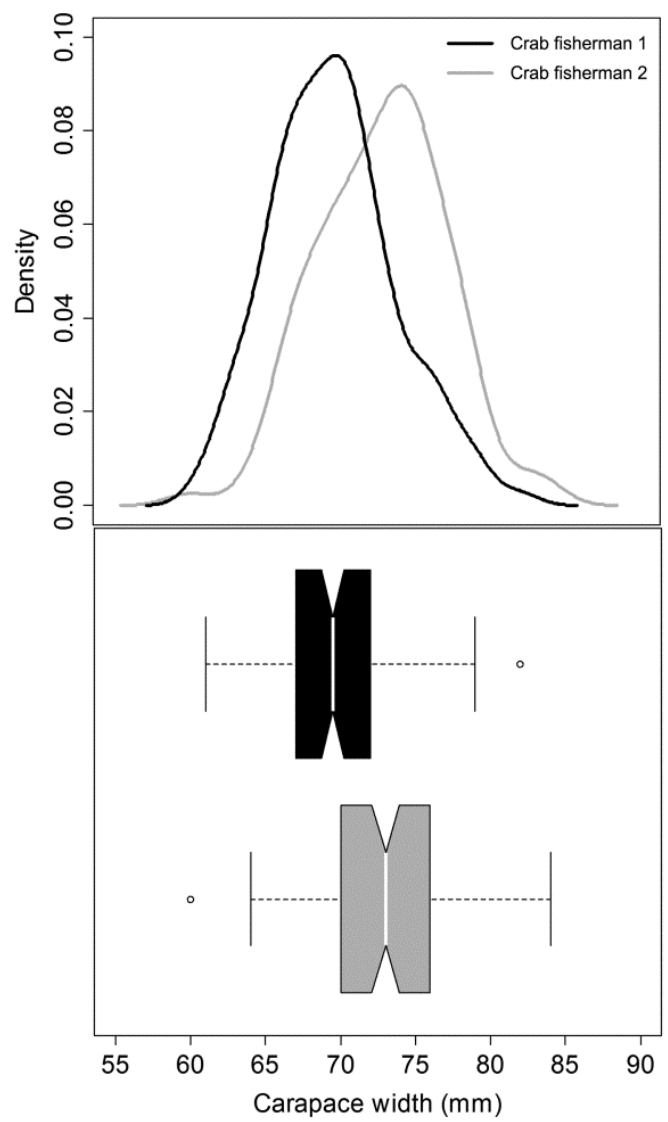

Fig. 2. Density curves for Ucides cordatus (above) and box plot showing medians (below), quartiles (lower and upper quartiles) and amplitude of the carapace width of specimens captured by two crab fishermen at Cananéia (SP, Brazil). 


\section{Capture Effort and Production Analysis}

Other studies have also used a GLM to select the exogenous variables that best determine the fishery production of squid (Loligo vulgaris, FONSECA et al., 2006), bluefin tuna (Thunnus maccoyii) (LU et al., 2008) and lobster (Scyllarides deceptor) (DUARTE et al., 2010). For this study, we analyzed 1,506 uçá crab fishing records, representing 234,918 specimens and a total production by weight of 70 tons. The use of the logarithmic transformation of CPUE for the GLM was necessary due to the asymmetric frequency distribution of the CPUE data (CRAWLEY, 2006). Diagnostic plots of the dispersion of the deviance residuals and of the envelopes for the components of the deviance show that the quartiles sampled by the ANOVA method tend to follow a homogeneous distribution and show the theoretical quartiles for the crab catches between January 2009 and December 2010. The quartiles are the three values that divide the sorted data set into four equal parts (25, 50 and $75 \%)$. Accordingly, each part represents one-fourth of the sampled data (Fig. 3). However, a normality test showed that the distribution of the log-transformed CPUE data was non-normal (SW: $\left.\mathrm{p}=2.2 \mathrm{E}^{-16}\right)$. The same figure shows that of the 1,506 observations, only $4.12 \%$ of the total data ( $n=62$ points), are outside of the specified ranges and cannot be explained by the GLM model. This result implies that the model has good explanatory value.

Tables 1 and 2 demonstrate that the variables represented by 'fisherman', 'year' and 'fishing sector' were the principal factors that significantly influenced the variation in CPUE for $U$. cordatus ( $\mathrm{p}<0.05$ ). Variation among the fishermen was the principal source of CPUE variation. This result shows that the individual fisherman's empirical knowledge was a leading determinant of the variation recorded in this study, as illustrated by the range in efficiency from $49 \%$ (fisherman 21, less efficient) to $114.8 \%$ (fisherman 11, more efficient) relative to fisherman 1. Such differences in particular environmental knowledge among fishermen are very common in traditional communities (FISCARELLI; PINHEIRO, 2002; WALTERS et al., 2008). Several types of fishermen differing in experience are active in the Cananéia region. The fishermen generally capture distinct types of fishery resources but may depend solely on $U$. cordatus captures. Accordingly, this information explains the differences in production efficiency among the fishermen observed in the present study (Fig. 4). This difference in capture efficiency among the fishermen may be due to their varying emphasis on crab fishing. Certain fishermen are known to diversify their activity by including catches of other seafood products, such as fish and oysters. Other fishermen are more efficient because they concentrate solely on the uçá crab. This knowledge influences the selection of the best fishing sites because the fishermen's operating routines and strategies for capture are closely related to the behavior of the crab and the environmental features that determine it (SOUTO, 2007).
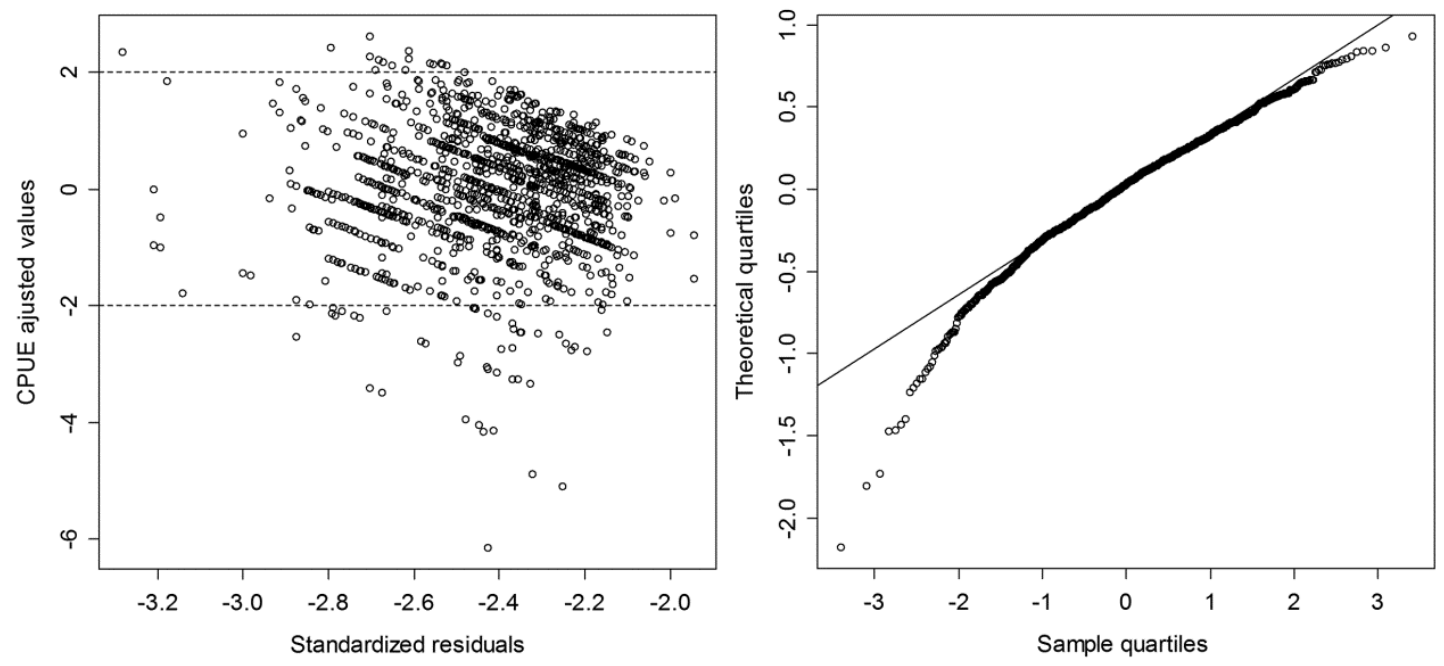

Fig. 3. Parameters describing the model of variation in CPUE $(\mathrm{kg} / \mathrm{h})$, represented by a diagram of the dispersion of the residuals (left) and the probability of the residual component of the standard deviation (right). 
Table 1. Deviance analysis for a General Linear Model (GLM) of uçá crab CPUE from January 2009 to December 2010 based on a gamma distribution with a logarithmic link (df, degrees of freedom; D, deviance; Res df, residual df; Res D, residual deviance). Asterisks indicate the level of significance: ${ }^{*} \mathrm{p}<0.05$, ${ }^{* *} \mathrm{p}<0.01$, *** $\mathrm{p}<0.001$ and ${ }^{\mathrm{ns}} \mathrm{p}>0.05$.

\begin{tabular}{llllllll}
\hline \hline Factors & df & D & Res df & Res D & F value & P $(>|\mathbf{F}|)$ \\
\hline Null & & & 1505 & 249.00 & & & \\
Fisherman & 26 & 47.78 & 1479 & 201.21 & 142.95 & $<2.20$ E-16 & $* * *$ \\
Year & 1 & 8.09 & 1478 & 193.12 & 629.79 & 4.13 E-12 & $* * *$ \\
Sector & 4 & 1.52 & 1474 & 191.60 & 29.48 & 0.019 & $*$ \\
Month & 11 & 3.19 & 1463 & 188.41 & 22.58 & 0.101 & $\mathrm{~ns}$ \\
Reproductive period & 1 & 0.18 & 1472 & 189.60 & 13.65 & 0.243 & $\mathrm{~ns}$ \\
Moon & 3 & 0.71 & 1460 & 187.70 & 18.33 & 0.139 & $\mathrm{~ns}$ \\
\hline
\end{tabular}

Table 2. Coefficients of a General Linear Model (GLM) of uçá crab CPUE from January 2009 to December 2010 for all factors, based on a gamma distribution with a logarithmic link (SE, standard error). Asterisks indicate the level of significance: $* \mathrm{p}<0.05, * * \mathrm{p}<0.01, * * * \mathrm{p}<0.001$ and ${ }^{\mathrm{ns}} \mathrm{p}>0.05$

\begin{tabular}{|c|c|c|c|c|c|c|c|}
\hline \multirow{2}{*}{$\begin{array}{l}\text { Factors } \\
\text { Constant }\end{array}$} & & \multirow{2}{*}{$\begin{array}{l}\text { Value } \\
.-3.22 \\
\end{array}$} & \multirow{2}{*}{$\begin{array}{l}\text { SE } \\
0.25\end{array}$} & \multirow{2}{*}{$\begin{array}{l}\mathbf{t} \text { value } \\
-1.25\end{array}$} & \multicolumn{2}{|l|}{$\mathbf{P}(>|\mathbf{t}|)$} & \multirow[t]{2}{*}{$\%$} \\
\hline & & & & & $<2.0 \mathrm{E}-16$ & & \\
\hline \multirow[t]{26}{*}{ Fisherman } & 2 & 0.44 & 0.09 & 4.81 & 1.7 E-06 & $* * *$ & 54.5 \\
\hline & 3 & 0.06 & 0.05 & 1.02 & 0.308 & ns & 6.2 \\
\hline & 4 & 0.64 & 0.26 & 2.43 & 0.015 & $*$ & 89.3 \\
\hline & 5 & 0.29 & 0.04 & 6.16 & 9.14 E-10 & $* * *$ & 33.7 \\
\hline & 6 & 0.56 & 0.09 & 5.76 & $1.03 \mathrm{E}-08$ & $* * *$ & 77.6 \\
\hline & 7 & 0.55 & 0.21 & 2.59 & 0.009 & $* *$ & 72.5 \\
\hline & 8 & -0.01 & 0.06 & -0.20 & 0.839 & ns & -1.3 \\
\hline & 9 & 0.35 & 0.04 & 7.85 & $8.28 \mathrm{E}-15$ & $* * *$ & 41.6 \\
\hline & 10 & 0.02 & 0.04 & 0.54 & 0.592 & ns & 2.4 \\
\hline & 11 & 0.76 & 0.26 & 2.91 & 0.004 & $* *$ & 114.8 \\
\hline & 12 & 0.33 & 0.05 & 5.63 & $2.13 \mathrm{E}-08$ & $* * *$ & 39.3 \\
\hline & 13 & -0.21 & 0.15 & -1.41 & 0.160 & ns & -19.1 \\
\hline & 14 & 0.19 & 0.04 & 4.05 & 5.46 E-05 & $* * *$ & 21 \\
\hline & 15 & 0.12 & 0.07 & 1.57 & 0.118 & $\mathrm{~ns}$ & 12.6 \\
\hline & 16 & 0.28 & 0.03 & 7.33 & 3.92 E-13 & $* * *$ & 32.2 \\
\hline & 17 & 0.32 & 0.06 & 5.25 & 1.75 E-07 & $* * *$ & 37.5 \\
\hline & 18 & 0.19 & 0.07 & 2.46 & 0.014 & $*$ & 20.5 \\
\hline & 19 & 0.21 & 0.05 & 3.80 & 1.48 E-04 & $* * *$ & 23.7 \\
\hline & 20 & -0.29 & 0.25 & -1.14 & 0.254 & ns & -25.5 \\
\hline & 21 & -0.69 & 0.14 & -4.90 & $1.06 \mathrm{E}-06$ & $* * *$ & -49.9 \\
\hline & 22 & 0.28 & 0.18 & 1.52 & 0.129 & ns & 32.5 \\
\hline & 23 & 0.24 & 0.05 & 4.23 & 2.52 E-05 & $* * *$ & 26.8 \\
\hline & 24 & 0.16 & 0.07 & 2.20 & 0.028 & $*$ & 17.9 \\
\hline & 25 & -0.36 & 0.06 & -5.44 & 6.36 E-08 & $* * *$ & .- 30.0 \\
\hline & 26 & 0.33 & 0.12 & 2.69 & 0.007 & $* *$ & 39.6 \\
\hline & 27 & 0.26 & 0.06 & 3.71 & $2.13 \mathrm{E}-04$ & $* * *$ & 29.4 \\
\hline Year & 2010 & 0.20 & 0.02 & 8.10 & $1.12 \mathrm{E}-15$ & $* * *$ & 21.8 \\
\hline \multirow[t]{4}{*}{ Sector } & $\mathrm{B}$ & 0.73 & 0.25 & 2.79 & 0.005 & $* *$ & 106.8 \\
\hline & $\mathrm{C}$ & 0.69 & 0.25 & 2.68 & 0.007 & $* *$ & 99.2 \\
\hline & $\mathrm{D}$ & 0.75 & 0.25 & 2.92 & 0.004 & $* *$ & 112.4 \\
\hline & $\mathrm{E}$ & 0.74 & 0.26 & 2.86 & 0.004 & $* *$ & 110.5 \\
\hline \multirow[t]{11}{*}{ Month } & Feb & 0.003 & 0.04 & 0.085 & 0.931 & $\mathrm{~ns}$ & 0.3 \\
\hline & Mar & 0.063 & 0.04 & 0.141 & 0.136 & $\mathrm{~ns}$ & 6.5 \\
\hline & Apr & 0.077 & 0.05 & 0.167 & 0.094 & ns & 8.0 \\
\hline & May & 0.11 & 0.05 & 0.245 & 0.140 & ns & 11.6 \\
\hline & Jun & 0.15 & 0.05 & 0.341 & 0.064 & $\mathrm{~ns}$ & 16.1 \\
\hline & Jul & 0.1 & 0.05 & 0.239 & 0.160 & ns & 10.5 \\
\hline & Aug & 0.079 & 0.04 & 0.186 & 0.062 & $\mathrm{~ns}$ & 8.22 \\
\hline & Sep & 0.11 & 0.04 & 0.261 & 0.089 & ns & 11.62 \\
\hline & Oct & 0.28 & 0.21 & 0.133 & 0.062 & $\mathrm{~ns}$ & 22.31 \\
\hline & Nov & 0.16 & 0.18 & 0.891 & 0.373 & $\mathrm{~ns}$ & 17.35 \\
\hline & Dec & 0.14 & 0.05 & 0.312 & 0.181 & ns & 15.02 \\
\hline $\begin{array}{l}\text { Biological } \\
\text { period }\end{array}$ & Reproductive & -0.03 & 2.24 & -1.25 & 0.212 & ns & -2.7 \\
\hline \multirow[t]{3}{*}{ Moon } & Waxing & -0.02 & 0.02 & -0.87 & 0.385 & ns & -2.2 \\
\hline & Waning & -0.03 & 0.02 & -0.99 & 0.322 & $\mathrm{~ns}$ & -2.6 \\
\hline & New moon & 0.03 & 0.02 & 1.05 & 0.292 & $\mathrm{~ns}$ & 2.8 \\
\hline
\end{tabular}




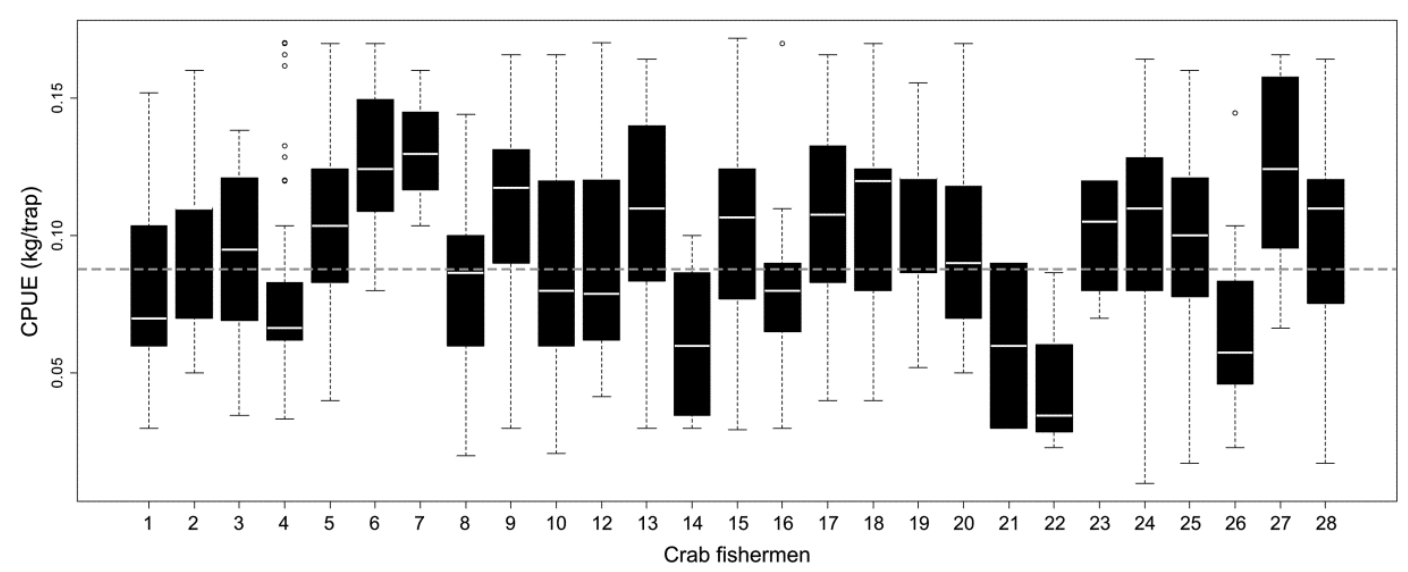

Fig. 4. Catch per unit effort (CPUE) of Ucides cordatus by crab fishermen at Cananéia (SP) in 2009 and 2010 (white line inside box, median; box, lower and upper quartiles; whiskers, amplitude). The broken horizontal line indicates the overall median CPUE (0.09 kg/trap).

The data show that a general expansion of the fishing sectors in the Cananéia region (Fig. 5A) occurred during the second year of the study, primarily as a result of the increase in fishing activity in sectors $\mathrm{A}$ and $\mathrm{E}$. These sectors are both relatively distant from urban areas. It is possible that this extension of fishing activity is related to the departure of some crab fishermen from the most frequently used fishing sectors (B, C and D), where crabs are commonly stolen from their traps by other fishermen. The fishermen in sectors $C(n=561)$ and $B(n=484)$ represented $69.4 \%$ of the total of 1,506 fishing records, whereas sectors $D(n=261), A(n=117)$ and $E$ $(n=83)$ were less frequently visited $(30.6 \%)$. Sectors $\mathrm{B}, \mathrm{C}$ and $\mathrm{D}$ experienced the heaviest fishing pressure, with a total of $81.9 \%$ of the fishing effort and 351,440 traps (Fig. 5B); the greatest number of crabs was recorded in sector $\mathrm{C}$, with 80,880 individuals captured for a total harvest of 26.9 tons (Fig. 5C). It is possible that this result is related to the greater ease of access to these sectors by fishermen due to the proximity of the sectors to the urban areas where the fishermen live.

In sector $\mathrm{A}$, the fishing effort increased from 2009 to 2010, corresponding to an additional 50,000 traps. This increase may represent an attempt by the fishermen to compensate for the distant location of the sector by minimizing the cost-benefit ratio resulting from the choice to fish farther from home. Although this sector shows the highest relative mean amount of fishing effort (Fig. 6A), it is also considered the most effectively protected site in the Cananéia area (CUNHA-LIGNON, et al. 2009). The excellent state of preservation of this sector is confirmed by many sightings of raccoons. These animals often eat trapped crabs (pers. comm. by local fishermen), and raccoon activity may have produced the relatively high number of failed traps observed in this sector (Fig. 6B).

The variable "sector" was also significant, according to the GLM. Fishing in Sector B was $106.8 \%$ more efficient than fishing in sector A. The same general pattern was found for the other sectors relative to sector A: C $(99.2 \%), \mathrm{D}(112.4 \%)$ and $\mathrm{E}$ (110.5\%) (Fig. 6C). Figure 7 shows the CPUE data by sector and year of capture, with Kruskal-Wallis (KW) tests (at 5\%) indicating a significant improvement from 2009 to 2010 in sectors B, C and D ( $<<0.05$; $\mathrm{KW}=8.30,20.35,36.98$, respectively). No differences were found between years in sector $E(p=0.52$; $\mathrm{KW}=0.40$ ). Only sector A showed a significant decrease in CPUE ( $p=0.03 ; \mathrm{KW}=4.56$ ). Mortality due to natural predation, in conjunction with the increased fishing effort in 2010, may explain the finding that the lowest fishing income was recorded in sector A (Fig. 6C). Although the other sectors also showed an increase in fishing effort, sector A may be the most sensitive to the effects of fisheries because the mortality resulting from natural predation is greater in that sector. Surprisingly, this study found that the relative abundance of the crabs was lower in sector A. Most likely, in fact - as well as in theory, this sector is in better ecological health than the other sectors. Accordingly, it is particularly important to recognize that the abundance of a particular species should not determine the outcome of an environmental quality diagnosis in a specific region. A holistic approach that considers the whole community should be used for this purpose. 


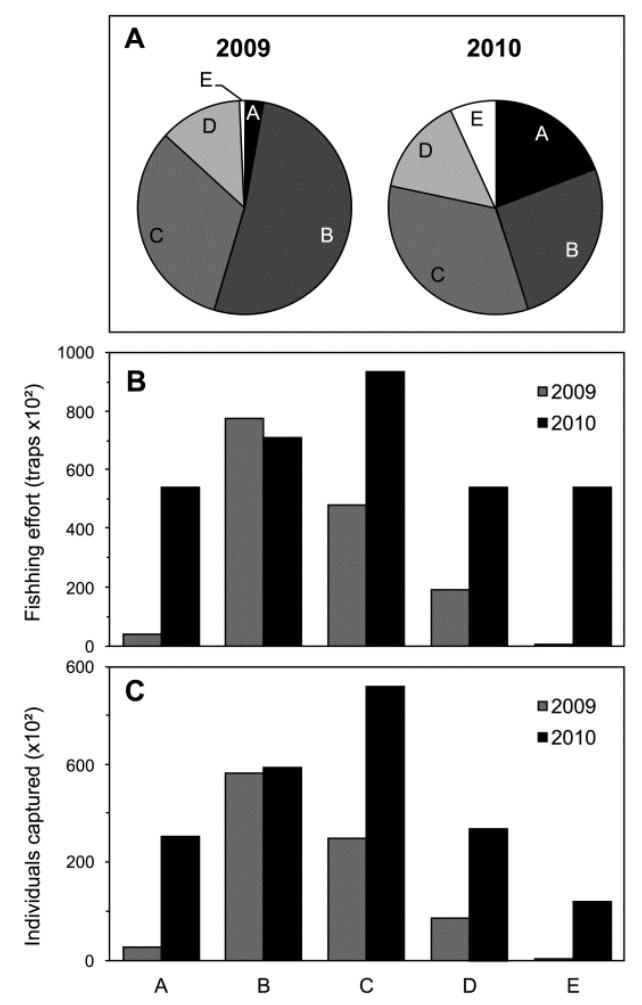

Fig. 5. Characteristics of the Ucides cordatus fishery (A, proportions of fishermen; B, number of redinha traps; C, number of specimens captured), with comparisons between 2009 and 2010, for the five fishing sectors at Cananéia (SP, Brazil).

The variable 'year' was also a significant variable in the model. The efficiency was $21.8 \%$ greater in 2010 than in 2009. This finding shows that the uçá crab population was recovering or tending to increase, an outcome different from that previously observed for $S$. deceptor (DUARTE et al., 2010). The GLM results show that the CPUE measure of the relative abundance of the uçá crab did not respond negatively to the increase in the number of traps (Fig. 8 ), in disagreement with the previous finding of Sparre and Venema (1998). The results of the present study show that fishing effort increased 1.9 times from 2009 (149,220 traps) to 2010 (279,480 traps), confirming that this species is not suffering from overfishing. It is possible that the abundant crab population is related to the presence of well-structured and well-preserved mangrove areas in Cananéia and is a response to the availability of a non-fragmented environment (CUNHA-LIGNON et al., 2009, 2011).

The variables 'month', 'reproductive period' and 'moon' were not significant in the model. However, although the factor 'month' did not produce significant changes in CPUE, October and November showed contrasting values when compared with the other months. It is possible that this result simply reflects a lack of data (October, $n=3$, November, $n=4$; all these observations were made in 2009). Because this period involved a closed season for the study species in the Brazilian south-southeastern (IBAMA, 2003 b), fewer data were available. Note that the use of the redinha trap allows the uçá crab to be harvested during the entire year and in all sectors of the fishery (Fig. 9). Moreover, this practice results in similar levels of productivity. If the fishermen had used certain traditional techniques permitted by law (e.g., 'braceamento') the productivity data would most likely be different. These traditional techniques would not maintain the level of productivity during the coldest months of the year, when the crabs move to greater depths in their burrows (WUNDERLICH et al., 2008).
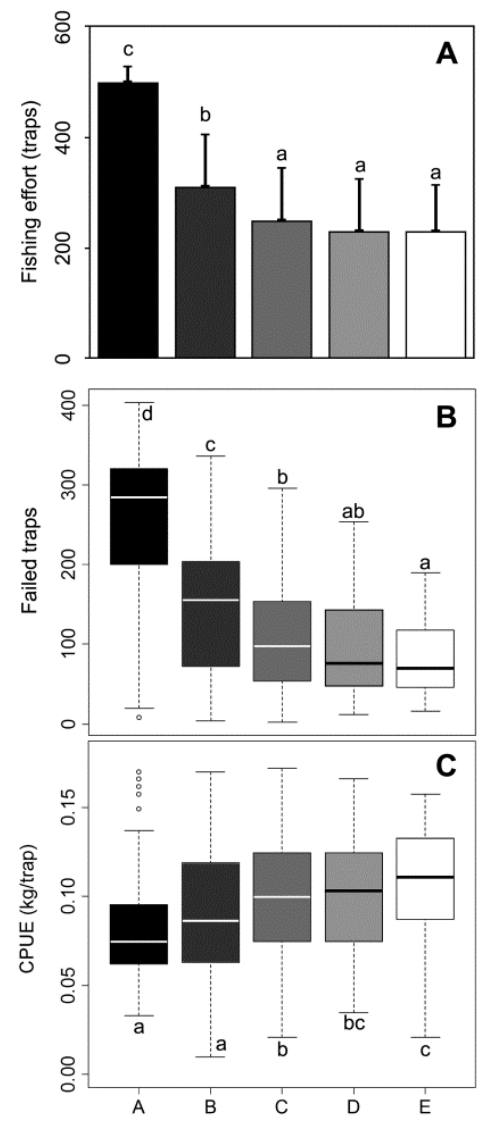

Fig. 6. Characteristics of the Ucides cordatus fishery by fishing sector (A to E) at Cananéia (SP) in 2009 and 2010: A) number of traps (bar, mean; vertical line, standard deviation); B) number of failed traps (white line inside box, median; box, lower and upper quartiles; whiskers, amplitude); and C) catch per unit effort (CPUE) with symbols similar to those in graph B. Different letters associated with the boxes indicate statistically significant differences between fishing sectors (Kruskal-Wallis test, 5\%). 


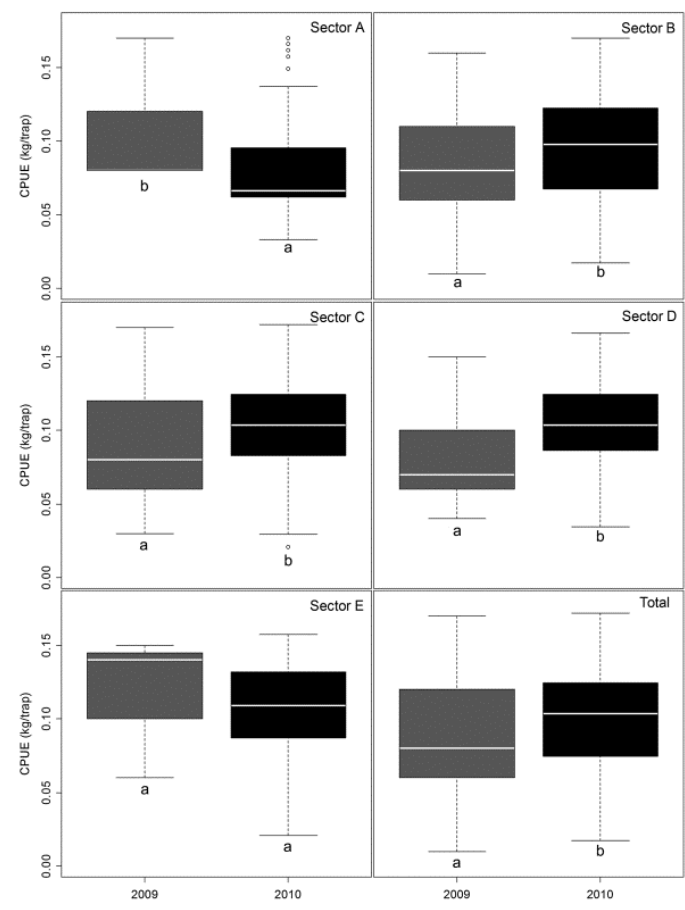

Fig. 7. Catch per unit effort (CPUE) of Ucides cordatus in five fishing sectors at Cananéia (SP) in 2009 and 2010 (white line inside box, median; box, lower and upper quartiles; whiskers, amplitude). Different letters associated with the boxes in the same fishing sector indicate statistically significant differences between years (Kruskal-Wallis test, $5 \%)$.

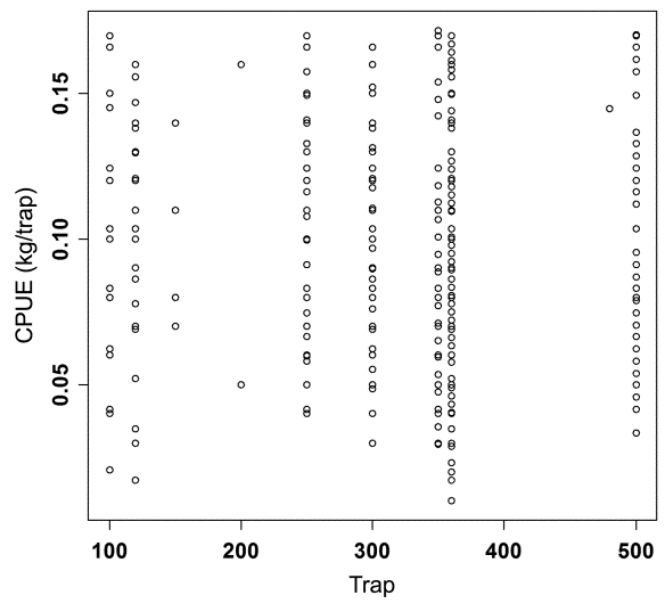

Fig. 8. Relationship between fishing effort (number of traps) and catch per unit effort (CPUE) of $U$. cordatus captured in Cananéia (SP, Brazil) between 2009 and 2010.

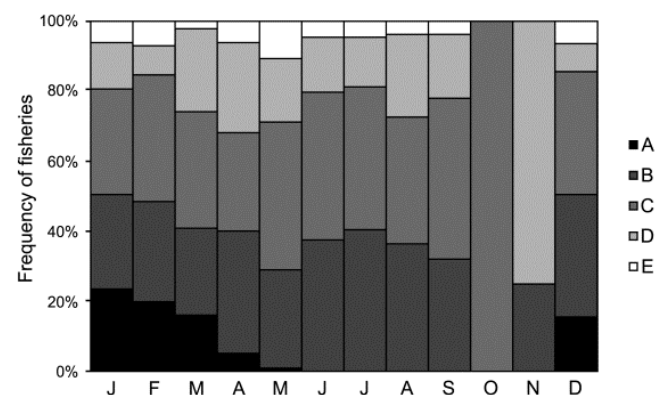

Fig. 9. Relative frequency of fisheries by sector on the Cananéia estuary (SP, Brazil) between 2009 and 2010, analyzed by month.

In conclusion, although redinha traps are prohibited by Brazilian laws, the results of this study do not indicate that the population of $U$. cordatus at Cananéia is currently threatened. These results are consistent with those presented by Diele et al. (2005), who found no evidence of overfishing in this species at Caeté Estuary (northern Brazil) despite 30 years of open-access exploitation. Based on these findings, we consider that $U$. cordatus is relatively more resistant to fishing pressure than other brachyurans (FAO, 2013). Obviously, as previously stated, other impacts are associated with the use of redinha traps, namely, passive fishing, the input of non-degradable material to mangrove areas and the mortality of young plants that results from the installation of the traps. The Brazilian government's supervision of control measures for controlling redinha traps is very reduced or virtually absent, primarily due to the difficulty of access to mangrove areas. Therefore, based on the results of this study, it is recommended that a type of trap similar to the redinha but constructed of biodegradable material should be developed, that improved monitoring should be conducted by environmental agencies and that the prohibition of this trap by Brazilian law should be reviewed. In this way, the sustainability of the fisheries examined in this study will be ensured, avoiding future overfishing and maintaining the fishing tradition, livelihood and financial stability of the crab fishermen of the Cananéia region.

\section{ACKNOWLEDGMENTS}

We thank all the crab fishermen of Cananéia city who provided essential information for this study, demonstrating a great interest in the sustainability of the uçá crab fishery resource. Additionally, special thanks are due to the Instituto de Pesca (Núcleo do Litoral Sul, Cananéia, SP) for allowing us access to their database. We acknowledge the input and help received from several colleagues, and we thank 
Gustavo Pinheiro for graphic design, mainly in relation to Figure 1. MAAP are grateful to $\mathrm{CNPq}$ for the research fellowships provided during this period, as well as to FAPESP for awarding financial aid for the same during Project Uçá III (\# 2009/14725-1).

\section{REFERENCES}

ALVES, R. R. N.; NISHIDA, A. K.; HERNÁNDEZ, M. I. M. Environmental perception of gatherers of the crab caranguejo-uçá (Ucides cordatus, Decapoda, Brachyura) affecting their collection attitudes. J. Ethnobiol. Ethnomed., v. 1, p, 1-8, 2005.

AMARAL, A. C. Z.; RIBEIRO, C. V.; MANSUR, M. C.; SANTOS, S. B.; AVELAR, W. E. P.; MATTHEWSCASCON, H.; LEITE, F. P. P.; MELO, G. A. S.; COELHO, P. A.; LOUREIRO, L.; VENTURA, R.; TIAGO, C. G. Invertebrados aquáticos. In: In: MACHADO, A.B.M.; MARTINS, C.S.; DRUMMOND, G.M. (Eds.). Lista da fauna brasileira ameaçada de extinção: incluindo as listas das espécies quase ameaçadas e deficientes de dados. Belo Horizonte: Fundação Biodiversitas, 2005. p.99-107.

ANDRADE, C. E.; VASCONCELOS, J. A.; OLIVEIRA, S. M, IVO, C. T. C. Biologia e pesca do caranguejo-uçá, Ucides cordatus (Linnaeus, 1763), no estuário do Rio Curimatau, Município de Canguaretama - Rio Grande do Norte. Bol. Tec. Cient. CEPENE, v. 15, n. 1, p. 31-41, 2007.

BOTELHO, E. R. O.; SANTOS, M. C. F.; PONTES, A. C. P. Algumas considerações sobre o uso da redinha na captura do caranguejo-uçá, Ucides cordatus (Linnaeus, 1763), no litoral sul de Pernambuco - Brasil. Bol. Tec. Cient. CEPENE, v. 8, n. 1, p. 55-71, 2000.

CRAWLEY, M. J. Statistics, An Introduction using R. Imperial College, London, UK. 327p., 2006.

CUNHA-LIGNON, M.; COELHO-Jr., C.; ALMEIDA, R.; MENGHINI, R. P.; SCHAEFFER-NOVELLI, Y.; CINTRÓN, G.; DAHDOUH-GUEBAS, F. Characterization of mangrove forest types in view of conservation and management: a review of mangals at the Cananéia region, São Paulo State, Brazil. J. Coastal Res., v. 57, p. 349-353, 2011.

CUNHA-LIGNON, M.; MAHIQUES, M. M.; SCHAEFFERNOVELLI, Y.; RODRIGUES, M.; KLEIN, D. A.; GOYA, S. C.; MENGHINI, R. P.; TOLENTINO, C. C.; CINTRÓN-MOLERO, G.; DAHDOUH-GUEBAS, F. Analysis of mangrove forest succession, using sediment cores: a case study in the Cananéia-Iguape coastal system, São Paulo-Brazil. Braz. J. Oceanogr., v. 57, n. 3, p. 161-174, 2009.

DALABONA, G.; SILVA, J. L.; PINHEIRO, M. A. A. Size at morphological maturity of Ucides cordatus (Linnaeus, 1763) (Brachyura, Ocypodidae) in the Laranjeiras Bay, Southern Brazil. Braz. Arch. Biol. Technol., v. 48, n. 1, p. 139-145, 2005.

DIAS-NETO, J. (Org.). Proposta de Plano Nacional de Gestão para o uso sustentável do caranguejo-uçá, do guaiamum e do siri-azul. Brasília: Ministério do Meio Ambiente, Instituto Brasileiro do Meio Ambiente e dos Recursos Naturais Renováveis, 2011. 156 p. (Plano de Gestão: Recursos Pesqueiros, 4). Available on:
file:///D:/Users/USER/Downloads/plano\%20nacional\%20car anguejo\%20ua\%20(2). pdf.Acessed in: 06.Sept.2013.

DIELE, K.; KOCH, V.; SAINT-PAUL, U. Population structure, catch composition and CPUE of the artisanally harvested mangrove crab Ucides cordatus (Ocypodidae) in the Caeté estuary, North Brazil: Indications for overfishing? Aquat. Living Resour., v. 18, n. 2, p. 169$178,2005$.

DUARTE, L. F. A.; SEVERINO-RODRIGUES, E.; GASALLA, M. A. Slipper lobster (Crustacea, Decapoda, Scyllaridae) fisheries off the southeastern coast of Brazil: I. Exploitation patterns between $23^{\circ} 00^{\prime}$ and $29^{\circ} 65^{\prime} \mathrm{S}$. Fish. Res., 102, n. 1, p. 141-151, 2010.

EGGERS, S.; PETRONILHO, C. C.; BRANDT, K.; JERICÓ-DAMINELLO, C.; FILIPPINI, J.; REINHARD, K. J. How does a riverine setting affect the lifestyle of shellmound builders in Brazil? Homo, v. 59, n. 6, p. 405-427, 2008.

FAO. Food and Agriculture Organization of the United Nations. Statistics of Fisheries and Aquaculture Department. 2013. Available on: http://www.fao.org/fishery/statistics/en. Accessed in: 15 Aug 2013.

FISCARELli, A. G.; PINHEIRO, M. A. A. Perfil sócioeconômico e conhecimento etnobiológico do catador de caranguejo-uçá, Ucides cordatus (Linnaeus, 1763), nos manguezais de Iguape ( $\left.24^{\circ} 41^{\prime} \mathrm{S}\right)$, SP, Brasil. Actual. Biol., v. 24, n. 77, p. 39-52, 2002.

FONSECA, T.; CAMPOS, A.; AFONSO-DIAS, M.; FONSECA, P. PEREIRA, J. Trawling for cephalopods off the Portuguese coast - Fleet dynamics and landings composition. Fish. Res., v. 92, n. 2/3, p. 180-188, 2008.

HERZ, R. Manguezais do Brasil. São Paulo. Instituto Oceanográfico, Universidade de São Paulo, 227 p., 1991.

IBAMA. Portaria n. 34, de 24 de agosto de 2003a. Dispõe do ordenamento da cata do caranguejo-uçá (Ucides cordatus) nas regiões norte e nordeste do Brasil. Available on: file://D:/Users/USER/Downloads/portaria\%20ibama\%2 0n34-2003-caraguejo\%20uca-no-ne.pdf. Acessed in: 02 Jul 2013.

IBAMA. Portaria n. 52, de 30 de setembro de $2003 b$. Dispõe da avaliação e ordenamento do caranguejo-uçá (Ucides cordatus) das regiões Sudeste e Sul do Brasil. Available

on: file:///D:/Users/USER/Downloads/documentos_legislao_ 51.pdf. Acessed in: 26 Oct 2013.

JANKOWSKY, M.; PIRES, J. S. R.; NORDI, N. Contribuição ao manejo participativo do caranguejo-uca, Ucides cordatus (L., 1763), em Cananéia - SP. Bol. Inst. Pesca, v. 32, n. 2, p. 221-228, 2006.

LEGAT, J. F. A.; LEGAT, A. P.; CASTRO, P. F.; PEREIRA, A. M. L.; GÓES, J. M.; FERNANDESGÓES, L. C. Current fishery status of Ucides cordatus (Linnaeus, 1763) (Brachyura, Ocypodidae) in the Parnaíba Delta Region, Brazil. Nauplius, v. 13, n. 1, p. 65-70, 2005.

LEGAT, J. F. A.; LEGAT, A. P.; PEREIRA, A. L. M.; GÓES, J. M.; GÓES, L. C. F. Caranguejo-uçá: métodos para captura, estocagem e transporte. Teresina: Embrapa Meio-Norte, 2006. 25 p. (Embrapa Meio-Norte. Documentos, 139). 
LU, J. L.; KAO, S. C.; CHENG, S. H. Relationships between CPUE fluctuation of southern bluefin tuna and ocean temperature variability in the Central Indian Ocean. Fish. Sci., v. 74, n. 6, p. 1222-1228, 2008.

MELO, G. A. S. Manual de identificação dos Brachyura (Caranguejos e Siris) do litoral brasileiro. São Paulo: Plêiade: FAPESP, 1996. 603 p.

MENDONÇA, J. T.; PEREIRA, A. L. C. Avaliação das capturas do caranguejo-uca Ucides cordatus no município de Iguape, litoral sul de São Paulo, Brasil. Bol. Inst. Pesca, p. 35, n. 2, p. 169-179, 2009.

NASCIMENTO, D. M.; MOURÃO, J. S.; ALVES, R. R. N. A substituição das técnicas tradicionais de captura do caranguejo-uçá (Ucides cordatus) pela técnica "redinha" no estuário do rio Mamaguape, Paraíba. Sitientibus: Ser. Cienc. Biol., v. 11, n. 2, p. 113-119, 2011.

PASSOS, C. A.; DI BENEDITTO, A. P. M. Captura comercial do caranguejo-uca, Ucides cordatus $(\mathrm{L} ., 1763)$ no Manguezal de Guargau, RJ. Biotemas, v. 18, n. 1, p. 223-231, 2005.

PINHEIRO, M. A. A.; FISCARELLI, A. G. Manual de apoio à fiscalização do caranguejo-uçá (Ucides cordatus). Itajaí: UNESP: Instituto Brasileiro do Meio Ambiente: Centro de Pesquisa e Gestão de Recursos Pesqueiros do Litoral Sudeste e Sul, 2001. 43 p.

PINHEIRO, M. A. A.; FISCARELLI, A. G.; BORBA, H.; SOUZA, C. A. Meat yield in mangrove crab Ucides cordatus (Linnaeus, 1763) (Crustacea, Brachyura, Ucididae). [In preparation].

PINHEIRO, M. A. A.; HATTORI, G. Y. Relative growth of the mangrove crab Ucides cordatus (Linnaeus, 1763) (Crustacea, Brachyura, Ocypodidae) at Iguape (SP), Brazil. Braz. Arch. Biol. Technol., v. 49, n. 5, p. 813823, 2006.

PINHEIRO, M. A. A.; OLIVEIRA, A. J. F. C.; FONTES, R. F. C. Introdução ao Panorama Ambiental da Baixada Santista. In: OLIVEIRA, A. J. F. C.; PINHEIRO, M. A. A.; FONTES, R. F. C. (Orgs.). Panorama ambiental da Baixada Santista. São Paulo: Universidade Estadual Paulista, Campus Experimental do Litoral Paulista, 2008. cap. 1 , p. $1-4$
PINHEIRO, M. A. A.; RODRIGUES, A. M. T. Crustáceos sobre-explotados e o plano nacional de gestão dos caranguejos uçá (Ucides cordatus), guaiamú (Cardisoma guanhumi) e do siri-azul (Callinectes sapidus): uma estratégia para evitar que passem ao "status" de ameaçados de extinção. Rev. CEPSUL, v. 2, n. 1, p. 5057, 2011.

SCHAEFFER-NOVELLI, Y.; CINTRÓN-MOLERO, G. Brazilian mangroves: a historical ecology. Cienc. Cult., v. 51, n. 3/4, p. 274-286, 1999.

SOUTO, F. J. B. Uma abordagem etnoecológica da pesca do caranguejo, Ucides cordatus, Linnaeus, 1763 (Decapoda: Brachyura), no manguezal do Distrito de Acupe (Santo Amaro-BA). Biotemas, v. 20, n. 1, p. 69-80, 2007.

SPARRE, P.; VENEMA, S. C. Introduction to tropical fish stock assessment. Part 1. Manual. 2. ed. Rome: Food and Agriculture Organization of the United Nations, 1998. 407 p. (FAO Fisheries Technical Paper, 306/1).

VANNUCCI, M. Os manguezais e nós: uma síntese de percepções. São Paulo: EDUSP, 1999. 233 p.

WALTERS, B. B.; RÖNNBÄCK, P.; KOVACS, J. M.; CRONA, B.; HUSSAIN, S. A.; BADOLA, R.; PRIMAVERA, J. H.; BARBIER, E.; DAHDOUHGUEBAS, F. Ethnobiology, socio-economics and management of mangrove forests: a review. Aquat. Bot., v. 89 , n. 2, p. 220-236, 2008. [Review].

WUNDERLICH, A. C.; PINHEIRO, M. A. A.; RODRIGUES, A. M. T. Biologia do Caranguejo-Uçá, Ucides cordatus (Crustacea, Decapoda, Brachyura), na Baía da Babitonga, Santa Catarina, Brasil. Rev. Bras. Zool., v. 25, p. 188-198, 2008.

ZAR, J. H. Biostatistical analysis. 4. ed. Upper Saddle River: Prentice Hall; London: Prentice Hall International, 1999. $123 \mathrm{p}$.

(Manuscript received 10 October 2013; revised 15 March 2013; accepted 10 April 2014) 